\title{
Brasileiros POR OPÇÃO: ALGUMAS PARTICULARIDADES DO PROCESSO DE EMANCIPAÇÃo POLÍTICA ENTRE O ACRE E O Rio Grande do Sul
}

\author{
José Sávio da Costa Maia ${ }^{1}$
}

RESUMO: Apresenta-se reflexões teóricas sobre elementos identitários utilizados por acreanos e gaúchos, percorrendo os recortes históricos e historiográficos que, nos dois estados, buscam construir singularidades distintivas de seu caráter nacional. Às afirmações de brasilidade optativa que os caracterizam, fazem parte de um discurso apropriado por setores dirigentes e outros segmentos sociais que, não raro, projetam sentimentos ambíguos, variando entre a distinção positiva da acreanidade/gauches, do ponto de vista interno, à conotação de "filhos enjeitados" da nação, situação que se expressa de forma mais aguda nas letras de seus hinos, especialmente quando se destacam os atos valorosos de bravura nas suas lutas "independentistas" contra os estrangeiros.

PALAVRAS-CHAVE: Identidade. Acreano. Gaúcho. Símbolo. Representação.

\section{Considerações iniciais: brasileiros por opção}

No contexto da História do Brasil, em que pesem os lapsos temporais que separam a formação dos Estados do Rio Grande do Sul (séc. XVII) e do Acre (séc. XIX), no que diz respeito à ocupação das terras por populações não índias, os processos seguiram modelos parecidos, ou seja, as terras não pertenciam a Portugal, no caso do primeiro, bem como não pertenciam ao Brasil, no caso do segundo, mas foram paulatinamente sendo ocupadas por segmentos de suas populações, seguindo a lógica da expansão fronteiriça, a ambição por terras e a exploração de produtos que permitissem a obtenção de lucros fáceis a partir de recursos naturais existentes.

Faz mister salientar que no caso do que hoje conhecemos como Rio Grande do Sul houve orientação expressa dos governos de Portugal para "ocupação" das terras, haja vista o interesse expansionista da Coroa Portuguesa (SOUZA, 1995, p. 154). Já no caso do Acre, tanto o Império, quanto à

${ }^{1}$ Doutor em História, Professor da Universidade Federal do Acre. 
República figuram como equidistantes do processo, aparecendo mesmo a República como reconhecedora da soberania boliviana sobre a região. ${ }^{2}$ Porém, as ideias de conquista, pioneirismo, aventureirismo, colonização, enriquecimento e exploração, além do argumento do uti possidetis influíam nas mentes e corações dos que, para além dos Impérios ou Nações, buscavam oportunidades de "fazerse na América", ou seja, a realização de negócios lucrativos.

Nos dois casos, por tratar-se de áreas fronteiriças, houve mobilização de tropas armadas e combates contra povos de outras nacionalidades, características que vão ao longo do tempo permitir a construção de traços peculiares ou diferenciadores dessas duas populações em relação aos outros estados da federação. Esse aspecto tornou comum aos líderes políticos e/ou componentes das elites em cada estado, arguirem a existência de elementos que compõem singularidades demarcatórias de identidades em relação aos outros Estados que completam nosso quadro federativo.

As características fronteiriças, o "isolamento" geográfico do que se considera o centro do país, a integração tardia e os tipos que caracterizam as suas populações (o gaúcho e o seringueiro), sendo apresentados como diferenciados ou mesmo assimétricos com relação aos dos outros estados, são recorrentes nos discursos de políticos e/ou elites locais nas relações estabelecidas com a República.

Compreender esse complexo quadro de reações e relações que fluxionam entre as categorias sociais distintas nesses dois espaços, não constitui tarefa muito simples, haja vista que o "orgulho de ser gaúcho" e o "orgulho de ser acreano", apresentam raízes relativamente profundas, adubadas

2 "Em 1895 foi nomeada uma comissão demarcatória encarregada de definir os limites entre o Brasil e a Bolívia de acordo com o estabelecido no Tratado de Ayacucho, de 1867. O chefe da delegação brasileira, o coronel Thaumaturgo de Azevedo, ao constatar a latitude da nascente do Javari, ponto inicial da linha divisória entre os dois países, percebeu que ficaria com a Bolívia uma região rica em látex, quase totalmente ocupada por brasileiros. Thaumaturgo de Azevedo denunciou ao governo federal o prejuízo daí decorrente, já que o Brasil perderia o alto Rio Acre, quase todo o Iaco e o alto Purus. Infelizmente o ministro brasileiro não aceitou os argumentos do coronel, que contrariado demitiu-se e denunciou o grave erro da diplomacia brasileira na imprensa, dando origem a uma intensa polêmica que mobilizou a opinião pública nacional". In. Revista Galvez, publicada pela Sec. de Cultura do Gov. do Estado do Acre - modelo on line. Pesquisa realizada em 14/7/2005. 
por suas bandeiras, seus hinos e seus heróis, como representações garantidoras de suas bravuras, de seus modos de agir, de pensar e de se comportar perante os valores que os consagraram como "optantes" pela nacionalidade brasileira, ao mesmo tempo em que podem funcionar como representação de inferioridade, desfavorecimento, ou mesmo de exclusão política, econômica e social, perante o restante do País.

Verificar como essas características identitárias, que na maioria das vezes, estão associadas a interesses político-econômico de governantes e elites podem ser também apreendidas pelas camadas menos favorecidas é a tarefa e o desafio aqui vicejados, embora saibamos que elas também podem ser pistas para entender certa perenidade na defesa desses símbolos pelos mais variados segmentos dessas elites locais.

Tentar-se-á, portanto, a partir de breve incursão na formação desses dois Estados, nos seus tipos, símbolos e nas letras dos seus hinos, buscar melhor posicionamento para comentar as peculiaridades desses filhos "optantes" de nossa "Mãe gentil" e "Pátria Amada, Brasil", trechos do Hino Nacional, também cantados com fervor tanto na "República Farroupilha" como no "Império de Galvez". 3

\section{Alguns antecedentes que contribuem para a construção das particularidades do acreano}

Até o início do século XX, o espaço geográfico que hoje se conhece como Estado do Acre era território pertencente à Bolívia. Desde 1870, no entanto, a maioria da população que ocupava a área já era formada por brasileiros que exploravam as "drogas do sertão" e logo depois, mais especificamente, os seringais para exploração do látex. No início da ocupação a característi-

\footnotetext{
${ }_{3}^{3}$ Luiz Rodrigues Galvez de Arias era um jornalista espanhol, com praça em Belém - PA que não tinha inicialmente nenhuma ligação com a questão do Acre. Sua inserção na história se dá após publicação de artigos em jornais paraenses denunciando o acordo que a Bolívia estava fazendo com os EUA onde este se comprometia a defendê-la em caso de guerra com o Brasil. Mesmo que a diplomacia estadunidense tenha negado o acordo, Galvez caiu nas graças dos seringalistas. Posteriormente, mostrou-se um hábil aglutinador de forças e foi ungido a situação de líder dos seringalistas que lutavam para expulsar as autoridades bolivianas da região. Governou o Estado Independente do Acre por oito meses de 14 de julho de 1989 a março de 1900.
} 
ca era o nomadismo, condicionado pela atividade predatória de extração do látex e das outras espécies vegetais que interessavam a economia colonial. Porém com a importância destacada do látex na indústria europeia e depois estadunidense, houve a necessidade de ocupação permanente, o que propiciou a formação de latifúndios (seringais), divididos comumente por obstáculos naturais, como rios, igarapés ou alguma elevação e sem medições precisas de fundo, já que era praticamente impossível realizá-las nas condições hoje conhecidas.

A ganância dos brasileiros pela ocupação daquelas áreas era estritamente comercial, já que os estudos dos franceses Charles Marie de la Condomine e François Fresnau, no final do século XVIII e, logo depois a descoberta do processo de vulcanização por Thomas Hancock, na Inglaterra e Charles Goodyear, nos Estados Unidos em 1844, tinham apontado a borracha como material de grande importância para a indústria (SANTOS, 1980. p. 43 a 45). Com a crescente demanda do produto para exportação e os impactos causados na balança comercial do Brasil, chegando a mais de quarenta por cento das exportações totais do País, os brasileiros que ocupavam a região criaram na prática um território independente e exigiram sua anexação ao Brasil.

Em 1899, os bolivianos começam a recolher imposto e fundaram Puerto Alonso (atual Porto Acre) na tentativa de assegurar o domínio da área. Os brasileiros que viviam na região se revoltaram, organizaram milícias e deflagraram lutas contra os bolivianos. Os conflitos só terminam com a assinatura do Tratado de Petrópolis, em 17/11/1903. Por esse tratado, o Brasil recebeu da Bolívia a posse definitiva da região em troca de áreas no Mato Grosso, do pagamento de dois milhões de libras esterlinas e do compromisso de construir a estrada de ferro Madeira-Mamoré, que favoreceria o acesso, os transporte e exportações bolivianas na sua área amazônica.

Integrado ao Brasil como território, o Acre foi subdividido em três departamentos: Alto Acre, Alto Purus e Alto Juruá, este último desmembrado em 1912 para formar o Alto Tarauacá. Tendo sido unificado em 1920, passou a eleger representantes para o Congresso Nacional a partir de 1934. Em 15/06/1962, o presidente João Goulart sancionou a lei que elevou o território à categoria de Estado (TOCANTINS, 1979). 
Esses episódios apresentados de forma rápida desfocam uma série de outras situações que foram se desenrolando ao longo dos anos para criar a condição de filho optante da nação brasileira. A guerra movida contra os bolivianos, que é denominada em nossa historiografia como "Revolução Acreana" e que teria sido um movimento espontâneo dos seringalistas e seringueiros contra as "intromissões" do governo boliviano, encobre um jogo de interesses que vai além da simples apropriação territorial e da isenção do governo brasileiro na disputa.

Os investimentos estrangeiros, principalmente ingleses, belgas e estadunidenses, a proposta feita por grupos bolivianos e anglo-americanos para organização do Bolivian Sydicate, uma espécie de consórcio que permitiria a presença estadunidense no território boliviano, inclusive com mobilização de tropas daquele país para a região e o monopólio de comércio e navegação nos rios da região, afetavam também os interesses geopolíticos dos Estados-Nacionais envolvidos. A até então alegada ausência do Estado brasileiro como participante ativo no processo não resiste a um olhar mais acurado sobre a questão, pois se não havia a disposição em participar dos eventos por parte do governo central enquanto Campos Sales era presidente, o mesmo não se pode dizer dos governos do Amazonas e do Pará, sendo que o primeiro chegou mesmo a contratar e enviar para a região duas forças expedicionárias, com intuito de afastar os bolivianos (TOCANTINS, 1979).

\section{Considerando-se o conceito de Estado $^{4}$ formulado por}

\footnotetext{
$\overline{4}$ Nos "Cadernos do Cárcere" existem três interpretações diferentes sobre a relação Estado/ sociedade civil. A primeira resultaria de diferenciações observadas por Gramsci entre as formações de sociedade do tipo "ocidental" e "oriental", que definiam ou condicionavam o tipo de relação dessa esfera com o Estado. Ou seja, nas formações de tipo "ocidental”, a sociedade civil era considerada mais "estruturada", mais "sólida", o que tornava o Estado "uma trincheira exterior da fortaleza da sociedade civil". Nas formações de tipo "oriental", a sociedade civil era percebida como pouco desenvolvida, "gelatinosa", nesse caso, o Estado é tudo. Desse modo, sua estratégia revolucionária estaria centrada, no primeiro caso numa "guerra de posição" e, no segundo, numa guerra de movimento. Segundo Perry Anderson, na primeira interpretação fica evidenciada, na percepção de Gramsci, a supremacia da sociedade civil em relação ao Estado nas formações ocidentais. Na segunda interpretação, Perry Anderson afirma que, ao contrário da primeira, a sociedade civil é apresentada como contrapeso do Estado ou em equilíbrio com ele, e a hegemonia é distribuída entre o Estado - ou a sociedade política - e a sociedade civil, sendo ela mesmo redefinida como combinando coerção e consentimento. Na terceira estaria a noção de Estado
} 
Antônio Gramsci, onde ele identifica-o como sendo um "complexo de atividades práticas e teóricas" constituído pelas esferas da sociedade política mais a sociedade civil, é possível pensar as ações desenvolvidas naquele espaço como expressão de processos econômicos e sociais conflitivos, pactuados politicamente e articulados ideologicamente no âmbito regional e mais, entender a região como parte do sistema Estado-Nacional. A partir dessa referência é possível entender as ações dos governos do Pará, do Amazonas, dos seringalistas e mesmo dos próprios seringueiros, não só na preservação de suas receitas geradas com o produto advindo do então território boliviano, como também a dissimulação do interesse brasileiro no mesmo.

Outro aspecto diz respeito às classes dominantes envolvidas diretamente no conflito, pois, primeiro criticavam a ausência do Governo Central assumindo o comando das ações em sua defesa, ao mesmo tempo em que queriam manter certa autonomia decisória, já que a ordem estabelecida lhes favorecia. É nesse sentido que se formava um quadro complexo, pois mesmo que houvesse interesses da parte dos revoltosos em manter um caráter de autonomia no movimento, os fatos posteriores, como a necessidade de controlar propriedades e conter as reivindicações das classes subalternas, foram mostrando a necessidade de organização que ultrapassava qualquer modelo espontâneo utilizado durante os conflitos e a ocupação anterior. Os próprios líderes dos "revoltosos" começavam a expressar posições divergentes, o que levou a formação de alianças, traições e urdiduras que culminaram no assassinato de vários deles, dentre os quais o próprio Plácido de Castro, considerado o maior líder da guerra contra os bolivianos e que figura hoje no panteão dos heróis brasileiros.

O ambiente formador do atual Estado do Acre, portanto, apresenta traços plurais no que tangencia suas relações político-institucionais. Como identificar a presença de uma sociedade civil interagindo com o Estado, se as organizações que participaram das escaramuças tinham lideranças que provinham de orientações militares e, mesmo que precariamente, agiam como tal, convivendo com outros "exércitos" liderados por seringalistas que mais se assemelhavam com os caudilhos rio-platenses?

ampliado. 
É possível perceber que não havia uma separação Estado/sociedade civil, que caracterizasse a "modernidade" nas relações estabelecidas naquele espaço, nem no momento da ocupação e nem mesmo depois da tomada do território. Nesse caso a entrada em cena da Diplomacia da República opera pelo alto ${ }^{5}$ uma arquitetura modeladora para ordenar o caos estabelecido.

Essa operação pelo alto realizada pela República, configurada no Tratado de Petrópolis (1903) e o estabelecimento do Território Federal do Acre, com nomeação de seus governantes (intendentes/prefeitos), direto pelo Governo Central é que gerará um redirecionamento no pensar e no agir das chamadas lideranças locais. O diálogo com o Poder Central passa a ser mediado pela postura da recusa a ser comandado, pois o valor da conquista foi mérito dos "nobres" que empunharam armas. Inicia-se o processo de construção dos arquétipos de valentes seringueiros, de defensores de seus direitos e de suas propriedades, de homens bravos e destemidos que mesmo sem o apoio desse Governo Central conseguiu derrotar um exército inimigo. Como diz parte do Hino Acreano:

Possuímos um bem conquistado

Nobremente com armas na mão

Se o afrontarem, de cada soldado

Surgirá de repente um leão. ${ }^{6}$

A idealização do herói, do vencedor, do estrategista e a disposição para lutar é, amplamente, reforçada neste outro verso:

Mas se audaz estrangeiro algum dia

Nossos brios de novo ofender

Lutaremos com a mesma energia

Sem recuar, sem cair, sem temer

E ergueremos, então, destas zonas

Um tal canto vibrante e viril

Que será como a voz do Amazonas

Ecoando por todo o Brasil. ${ }^{7}$

Em versos que falam de liberdade, de guerra, de sangue,

\footnotetext{
5 "Pelo alto", é uma expressão usada no sentido de que não houve ruptura entre "atraso" e "moderno", cabendo ao Estado a direção política do processo (COUTINHO, 1988, p. 112-114).

${ }^{6}$ O Hino Acreano tem letra do médico Francisco Mangabeira e música de Mozart Donizetti, e foi composto em 05/10/1903, ou seja, bem no momento da "Revolução Acreana", talvez por isso conserve um caráter belicoso e apresenta orientações para um tipo de "organização social".

${ }^{7}$ Idem.
} 
de família, de heróis, há a expressão de um determinado modo de vida que foi sendo construído (inventado), da forma autônoma, diferente, onde a bandeira tem como destaque uma estrela vermelha, "tinta no sangue de heróis" e ao cantar o triunfo diz que “O Brasil a exultar acompanha”, isto é, não lutou, apenas acompanha os passos dos vitoriosos, indicando a ideia de autonomia e a predisposição de se manter vigilante.

Não há como afirmar que essa disposição de luta, de vigília, também é contra ou em relação ao Brasil, mas também não há como negar que a condição de Território ao invés de um Estado da Federação, causou incômodo a muitos dos líderes da "Revolução Acreana", que por duas vezes já haviam criado o Estado Independente do Acre: A primeira com o jornalista espanhol Luiz Galvez em 1899 e a segunda com o militar gaúcho José Plácido de Castro em 1903.

Outro fato notório nessas relações político-institucionais é o que diz respeito aos seringueiros propriamente ditos. Eles participaram ativamente das escaramuças, mas sempre em condição de recrutados e liderados por seus patrões (seringalistas), que recebiam a patente de capitães e estavam ligados aos superiores militares não possuidores de terras. O rotulado "Primeiro manifesto" contra a presença dos bolivianos na região foi assinado por sessenta proprietários de seringais (seringalistas) e que no decorrer das escaramuças esse número cresceu sem, contudo, haver números precisos de quantos seringalistas se alistaram ao lado dos militares e/ou mercenários enviados pelo governo do Amazonas para a contenda. Porém, os registros de participação popular apontam para ações subalternas e no caso das mulheres, que naquela época eram bem poucas na região, apenas uma ganhou destaque de heroína por comandar uma patrulha, é o caso da esposa de um seringalista morto em combate, que queria vingar a morte do marido (TOCANTINS, 1979).

Efetivamente, a adesão de seringueiros à causa revoltosa não se dava por simpatia aos patrões, muito pelo contrário, segundo Moreno, um dos méritos de Plácido de Castro, que não era seringalista, foi exatamente o de pensar além do episódio da guerra em si (MORENO, 14/07/2005). Ele elaborou ideias para o pós-guerra, onde previa uma reorganização da estrutura social e 
produtiva da região, prevendo inclusive a distribuição de terras entre os seringueiros. Esse fato contribuiu para a arregimentação, mas também para dar início aos conflitos de interesses entre os diversos níveis de proprietários que viam com preocupação a possibilidade de perder suas propriedades e por consequência a mão-de-obra tão escassa nas áreas de seringais.

\section{O estrategista Plácido de Castro percebeu que a mobi-} lização de homens, não se daria por amor à Pátria ou ao Estado independente pretendido por alguns. A arregimentação de braços para manejar as espingardas e os rifles necessitava de outros atrativos e ele logo entendeu que a estrutura social montada pelos seringalistas não contribuía para o engajamento, já que as impossibilidades de ascensão social estavam totalmente engessadas pelos mecanismos da dívida e do aviamento. Assim como as promessas de alforria para os negros na Guerra do Paraguai, as promessas de distribuição de terras e libertação das dívidas funcionaram como incentivo para o fortalecimento das hostes placidianas.

Pode-se fixar, portanto, nesse contexto, duas variantes que imprimem certa diferença do acreano com relação aos outros brasileiros. Uma, o fato de ter ajudado a construir uma situação jurídica e geopolítica diferente para aquela parte do território e, outra, a ação de muitos seringueiros aspirando à desmontagem de uma ordem estabelecida que os mantinham aprisionados às regras draconianas impostas pelos seringalistas.

Essas duas vertentes que compeliam para a guerra seringalistas e seringueiros eram insolvíveis no jogo de interesses das disputas estabelecidas pelo regime engendrado para a extração do látex e as relações comerciais daí derivadas. Vencido o entrave boliviano, outra modelagem havia de ser montada. Nesse sentido, o ordenamento político pensado pelas elites dirigentes precisava ser adequado para a manutenção da ordem, iniciando outro campo de disputas, agora pela apropriação do poder inserto pela incorporação ao Brasil.

O episódio da guerra movimenta agentes que na estrutura do aviamento estavam engessados, como é o caso dos seringueiros, apresenta outros, como os militares que não estavam presentes anteriormente e introduz os funcionários públicos, implicando a reordenação da composição do poder. Essa nova situação vai propiciar no decorrer das disputas a reacomodação de forças 
e a elaboração de uma nova maneira de apresentar o acreano como portador de valores que foram fusionados no curso do processo emancipatório.

A autonomia, a liberdade, a "nobreza, a constância e o valor" como diz uma estrofe do Hino Acreano, são cotejadas como características inatas. Então, o acreano que é diferente, que ocupa espaços diferentes tanto na estrutura econômica quanto na político-social, é apresentado como homogêneo, pertencente e incluído pelo menos ideologicamente, nas formulações dos que pleiteiam a cristalização de uma identidade imaginada.

A identidade passa, então, a ser usada como arma para galgar espaços e posições na nova estrutura administrativa do, naquele momento, Território Federal. Os "vencedores" militares e seringalistas reivindicando para si o direito de exercer o poder sobre os vencidos, ou seja, os seringueiros (esqueçamos os bolivianos). Seriam os bolivianos os inimigos? Os donos dos seringais passam a disputar a manutenção do poder com os militares que queriam também ser proprietários e, principalmente com os novos dirigentes políticos, enviados pelo poder central para preencher os cargos criados pela nova estrutura política do ente jurídico Território Federal.

Desse modo, a ocupação do espaço territorial boliviano, a "Revolução Acreana", e seu reordenamento jurídico com a incorporação ao Brasil produzem significativas modificações no ente político, sem afetar diretamente a estrutura econômica, mas implicando maior divisão do poder dos seringalistas que, até então, só interagiam de forma subordinada com os financiadores e as casas aviadoras e exportadoras.

É nesse sentido que há o fortalecimento de uma ideia de que os seringalistas e os seringueiros agiam de forma coordenada, os líderes dispostos a liderar e os subordinados dispostos a colaborar, inventando a noção de que havia causas nobres que venciam preconceitos e uniam os interesses diversos e conflitantes. Em suma, um povo que não podia ter seus brios (seus interesses) ofendidos, pois a reação seria uníssona, já que são: "Invencíveis e grandes na guerra".

\section{Alguns elementos constitutivos das particularidades do gaúcho}

Quando se estuda a História do Brasil, ou mesmo os as- 
pectos geográficos apresentam-se nos alguns tipos, figuras e cenários que representam as diversas regiões. As referências a tipos como o bandeirante, a baiana, o seringueiro, o garimpeiro, o nordestino retirante, o sambista carioca, o jeca tatu, o gaúcho, etc., são corriqueiras. Obviamente, com os meios de comunicação atual as possibilidades de enxergar outras realidades ajudaram a desatar alguns fios dessas teias que enredavam nossa composição social. Porém, até poucos anos, no contexto de uma população que não viajava ou viajava pouco, os livros e as revistas que privilegiavam a exaltação das diferenças, expandiam e homogeneizavam visões distantes da realidade de uma região para as outras.

Para pessoas de outros Estados, um dos tipos brasileiro mais distinto é o gaúcho. Sua forma de representação, composta por seus trajes, seu cavalo, sua cuia de chimarrão, seu laço e seu bigode, são reconhecidos facilmente enquanto representante do Rio Grande do Sul. Esse resultado que propõe "A redução de homens em tipos contribui para que concepções generalizantes se estabeleçam como forma de conhecimento e reconhecimento prévio servindo para encobrir determinadas situações sociais", conforme assinala Maciel em trabalho que estuda tipos característicos, região e estereótipos regionais (MACIEL, 1995).

Assim a população do Estado do Rio Grande do Sul, foi e é apresentada as outras regiões do país com essas características reveladoras, ou portadoras de significados que expressavam e expressam de forma generalizante "ideias que os habitantes dessa região tem, querem ter ou querem que os outros tenham sobre eles mesmos" (MACIEL, 1995, p. 173). Mas, quais são esses significados?

O processo de ocupação das terras do que hoje compõe o Estado do Rio Grande do Sul, embora conhecidas desde o século XVI, só ganhou relevo no final do século XVII, desencadeando uma forma de expansão fronteiriça onde a violência, as intempéries, à distância, o isolamento, as perdas materiais e humanas acompanhavam os empreendedores. No dizer de Ruben Oliven:

Apesar da diversidade interna do estado (a ponto de um autor falar em "doze Rio Grandes), a tradição e a historiografia regional tendem a representar seu habitante através de um 
único tipo social: o gaúcho, o cavaleiro e peão de estância da região sudoeste do Rio Grande do Sul. Embora brasileiro, ele seria muito distinto de outros tipos sociais do país, guardando às vezes mais proximidade com seu homônimo da Argentina e do Uruguai. Na construção social da identidade do gaúcho brasileiro há referência constante a elementos que evocam um passado glorioso no qual se forjou sua figura, cuja existência seria marcada pela vida em campos, a presença do cavalo, a fronteira cisplatina, a virilidade e a bravura do homem ao enfrentar o inimigo ou as forças da natureza, a lealdade, a honra, etc. (OLIVEN, 1992, p. 49/50).

Porém, para chegar ao perfil senso-comum atual, a figura do gaúcho como asseverou Oliven (1992, p. 50), "sofreu um longo processo de elaboração cultural”, ou seja, não é um resultado natural de moldagem tipológica. No caso do gaúcho, também precisamos estudar as variáveis econômicas, sócio -políticas e culturais para entender a que projeto de organização pensada para esse espaço, servia melhor seu perfil, pois a ressemantização do termo que foi acontecendo ao longo do tempo também obedeceu a esses imperativos.

O longo processo de guerras, passando pela Cisplatina, Farroupilha e, do Paraguai, além dos conflitos com indígenas, não podem ser descartados na configuração do homem valente, que precisava estar pronto para a ação, aspecto que é reforçado pela lida com gado xucro e da própria paisagem. Érico Veríssimo, num trecho em que responde a uma escritora nordestina que creditava espanholismos aos gaúchos (Apud OLIVEN 1992, 48), assim descreve seu modo de ver o gaúcho:

Somos uma fronteira. No século XVIII, quando soldados de Portugal e Espanha disputavam a posse definitiva deste imenso deserto, tivemos de fazer a nossa opção: ficar com os portugueses ou com os castelhanos. Pagamos um pesado tributo de sofrimento e sangue para continuar desse lado da fronteira meridional do Brasil. Como pode você acusar-nos de espanholismos? Fomos desde os tempos coloniais até o fim do século um território cronicamente conflagrado. Em setenta e sete anos tivemos doze conflitos armados, contadas as revoluções. Vivíamos permanentemente em pé de guerra. Nossas mulheres raramente despiam o luto. Pense nas duras atividades da vida campeira - alçar, domar e marcar potros, 
José Sávio da Costa Maia

conduzir tropas, sair da faina diária quebrando a geada nas madrugadas de inverno - e você compreenderá porque a virilidade passou a ser a qualidade mais exigida e apreciada do gaúcho. Esse tipo de vida é responsável pela tendência algo impetuosas que ficaram no inconsciente coletivo deste povo, e explica a nossa rudeza, a nossa às vezes desconcertante franqueza, o nosso hábito de falar alto, como quem grita ordens, dando não raro aos outros a impressão de que vivemos num permanente estado de cavalaria. A verdade, porém, é que nenhum dos heróis autênticos do Rio Grande que conheci jamais proseou, jamais se gabou de qualquer ato de bravura seu. Os meus coestaduanos que, depois da vitória da Revolução de 1930, se tocaram para o Rio, fantasiados, e amarraram seus cavalos no obelisco da Avenida Rio Branco - esses não eram gaúchos legítimos, mas paródias de opereta (OLIVEN, 1992, p. 48).

Note-se que mesmo Érico Veríssimo, com toda a sua capacidade intelectual, aguçado senso crítico e capacidade de capturar detalhes, como demonstrada em toda sua extensa obra e considerando que o fragmento acima é um resumo da sua apreensão do gaúcho, vemos que ele apresenta apenas a sublimação de certo tipo que mantém as características da homogeneidade e do perfil voluntarioso, másculo, altivo, mas não consegue expressar a diversidade dos agentes que interagiram nos processos de guerras e "revoluções" vividas pelos rio-grandenses ao longo do século XVIII e XIX, os negros, os índios e as mulheres praticamente não aparecem na composição do tipo que ganha o direito de representar o Estado, embora saibamos que em sua obra mais geral ele reconhece, destaca, prioriza até, a diversidade.

Outro fragmento, este da obra de José de Alencar, citado por Pesavento, mostra a ligação natureza-homem numa forma extensiva daquela, neste:

Nenhum ente, porém, inspira mais energicamente a alma pampa do que o homem, o gaúcho. De cada ser que povoa o deserto, toma ele o melhor: tem a velocidade da ema ou da corsa, os brios do corcel e a veemência do touro. O coração, fê-lo a natureza franco e descortinado como a vasta coxilha, a mesma pujança. A esse turbilhão do sentimento era indispensável uma amplitude de coração, imensa como a savana (PESAVENTO, 1995, p. 221). 
Outros fatores que chamam a atenção para o caso do perfil do gaúcho são suas bases e perenidade. Oliven (1992, p. 51) destaca que desde relatos de viajantes estrangeiros, como Saint-Hilaire e Arsène Isabelle, passando por escritores nacionais, como José de Alencar e pensadores como Oliveira Vianna, o destaque para o tipo gaúcho é significativo.

Além do gaúcho bravo, ágil, etc., há certa idealização do gaúcho politizado, com forte tez democrática, possuidor de uma conduta moral inatacável, regida por princípios éticos inabaláveis, onde o dono da estância sorve um chimarrão na mesma cuia com o peão, comanda tropas, trabalha na vaquejada também montado como aquele e que abraça, no dizer de Simões Lopes Neto, uma característica de trabalho prazeroso, composto por um fazer natural, a lida campeira:

Tudo era aberto; as estâncias pegavam uma nas outras sem cercas nem tapumes; as divisas de cada uma estava escrita nos papéis das sesmarias; e lá um que outro estancieiro é que metia marcos de pedras nas linhas e isso mesmo quando aparecia algum piloto que fosse entendido do ofício e viesse bem apadrinhado (LOPES NETO, 1996. p. 49).

Ou seja, era um conjunto que se mantinha porque havia uma aceitação coletiva: "Tudo era aberto". Contudo, essa visão já carrega um modelo de idealização. A apresentação de um homem que tinha o céu como seu teto, e seu rumo era traçado pelo destino, só pode ser aplicado a parcelas reduzidas daquela população e a períodos também distintos, o que torna intrigante a perenidade, a permanência da figura do homem a cavalo e a mistificação que o acompanha, pois há que se notar a incongruência do estilo de vida solitário do vaqueano com a forma de vida sedentária das estâncias, pois já vai bem distante o tempo das vaquejadas nas campanhas do período inicial da ocupação da região.

Outro aspecto idealizado é a abertura que se dizia haver da terra. Uma idealização que fatalmente contrastaria com a realidade das cercas, dos títulos, das próprias patentes militares adquiridas nas várias guerras em que estiveram envolvidos esses agentes, que resultavam na maioria das vezes, na apropriação de um botim. Essa hierarquização social não permite uma aceitação tranquila da igualdade professada. Isto é, homens de negócios, estancieiros, militares, 
comerciantes, charqueadores, peões todos reunidos numa convivência pacífica, é praticamente inimaginável em qualquer tempo, pois está patente que onde as disputas comandam as ações e as relações de comércio, produção, administração e distribuição, tanto do poder como dos bens de uso e consumo se caracterizam pela competição, nem sempre há ética e respeito de valores morais, que tenham fluxo contínuo e inverso entre as hierarquias estabelecidas.

Porém, mais chamativa é a noção de cordialidade, honra e virtuosidade do gaúcho, como na letra do Hino do Rio Grande do Sul:

Mas não basta ser livre

ser forte, aguerrido e bravo

o povo que não tem virtude, acaba por ser escravo.

A quem se dirige o clamor à virtude? Será uma mensagem aos grandes estancieiros para que tratem os negros, índios e mulheres como iguais, que respeitem os limites e propriedades dos outros? Ou será uma exortação à vigília contra o Império brasileiro, no sentido de manter a autonomia dos estancieiros, comerciantes, charqueadores, coureiros, etc., alertando para a manutenção do ordenamento tradicional, que vinha dando certo para esses setores?

Não se tem notícia no Rio Grande do Sul, de movimentos estritamente de negros e índios organizando manifestos prós ou contra Império ou República, discutindo emancipação política e autonomia na forma de um Estado independente, República rio-grandense, ou qualquer configuração similar onde estivesse intuída uma ampla frente compondo todas as categorias que interagiam no espaço da campanha. Participaram, mas de forma subalterna, liderados e, podemos até dizer, vigiados. Os movimentos de negros e índios sempre tiveram outra direção, distanciar-se dos "brancos".

Esse papel coube, fundamentalmente, aos grandes proprietários e membros da elite local. E mais, sua construção obedecia a elementos de manutenção e ampliação de negócios e distribuição e manutenção de poder, numa relação criativa e pseudo-inclusiva, onde a partir de dentro se projetava a imagem idealizada de um destino comum. Segundo Pesavento (1995, p.118): 
Concentrando em si os atributos positivos da região e do seu povo - coragem, caráter indômito, defensor da fronteira -, a imagem identitária é trabalhada no sentido de homogeneizar a sociedade. A visualização é a de um homem simples do pampa, mas seu fim manifesto é a socializar-se para todos os habitantes do Sul, oferecendo uma imagem gratificante e com alto poder coesivo. Não se falam em diferenças sociais dentro do Rio Grande - tal como no nordeste -, pois as reais oposições a vencer estão fora da região. Expurga-se o conflito, criando o "inimigo externo" (PESAVENTO, 1995, p. 118).

A aceitação dessa sociedade idealizada por amplas parcelas dos diversos estratos sociais é o fenômeno intrigante no estudo das representações tipológicas apresentadas. Os detentores do poder econômico se fazem também portadores do poder político, engendrando uma arquitetura social que permite os outros segmentos sociais se verem incluídos nesse processo. Como o negro, os remanescentes indígenas e os segmentos urbanos e de outros setores sociais apreendem os mecanismos de representação e popularizam os modelos disponibilizados. Esse é um caminho que ainda necessita de melhores aportes teóricos para ser desvelado. Qual seria o tipo de troca, de compensação para a assimilação ter essa característica tão bem fundamentada e tão perene?

\section{Considerações finais: Acre, Rio Grande do Sul e a ideologia que os aproxima}

Como foi dito anteriormente, os movimentos constitutivos dos estados do Acre e do Rio Grande do Sul, se deram em espaços temporais distintos e com características que também preservam boas diferenças. Mas, no conjunto é possível identificar-se algumas aproximações, principalmente no que diz respeito à formação de suas elites governantes, nos dois casos baseadas em grandes proprietários (estancieiros - seringalistas), militares, comerciantes e altos funcionários públicos, cristalizando configurações internas de poder de mando e orientando seus relacionamentos com a República.

Nos dois casos houve a aplicação de um conjugado de valores que tiveram e mantém um grau de aceitação interno e externo de longa duração que regulam seus relacionamentos de aceitação ou rejeição de políticas 
advindas do governo central. Tratam e são tratados de forma diferenciada com a República, estabelecendo variações, ambiguidades, contradições, oposições e colaboração que oscilam entre práticas benéficas e/ou maléficas para os interlocutores, comumente expressando uma visão maniqueísta nesse relacionamento.

O fato dos dois estados terem participado de forma marcante de guerras contra outros países e de terem convivido com governos independentes, tendo para isso contado com milícias próprias, facilitou o surgimento de (principalmente no caso do Rio Grande do Sul, onde se desenvolveram algumas guerras mais prolongadas e um estado independente mais duradouro) uma forte acepção rebelde, autonomista (independentista?) e às vezes separatista, que em menor grau, mas também perceptível, existiu em alguns setores das elites dominantes no Acre, hoje, praticamente inexistente.

Outro aspecto que une os dois estados diz respeito ao tratamento destinado às questões econômicas. Setores governantes do estado do Acre, por exemplo, reclamam de já ter sido responsável por percentual elevado das exportações brasileiras no início do século XX e nunca ter sido ressarcido, ou seja, nunca ter recebido investimentos por parte da União que reconhecesse sua contribuição naquele período, portanto, elaboram com certa facilidade o discurso do filho "enjeitado", o filho que optou, que lutou para ser brasileiro, mas persiste sendo olhado de soslaio, como bastardo, pela Pátria-mãe.

Essa característica de optante não reconhecido também é observável no Rio Grande do Sul, com a agravante de que aqui perdura um movimento separatista que argui com certa ressonância fatores relacionados à contribuição atual do estado ao PIB brasileiro, também sem a devolução em benefícios e subsídios à população e aos produtores, com o argumento de que, se administrassem aqui suas riquezas o estado seria mais bem aquinhoado, pois, pelas características democráticas e atributos de bons administradores que possuem, os recursos seriam mais bem aproveitados.

As articulações dos discursos que permitem a interlocução com a República são orientados por questões que tem como fundamento a economia e o acesso ao poder político, contudo, não se descuidam de alguns 
fatores sociais para garantir a adesão das demais categorias que compõem o todo. Com efeito, essas elites elaboraram e difundiram complexos conceitos ideológicos, que ressaltam a unidade federativa e a singularidade como fenômenos abrangentes e objetos da ação de todos para concretizá-los.

Sabe-se, no entanto, que somente a força de um milagre monumental poderia fazer as relações de dominação e subordinação estrutural entre Estados e os setores ditos civis, tomarem formas diferentes das que assumiram ao longo do seu desenvolvimento histórico, isto é, o Estado colocado a serviço de determinada ordem social estabelecida, favorecendo aos setores que dominam suas estruturas. Portanto, seria absurdo até mesmo sugerir que das determinações internas estruturais, praticamente inalteráveis, desse sistema pudessem surgir e se solidificar relações que não fossem desiguais, ou seja, a ideologia usada pelas elites dominantes nos dois estados para regular seu relacionamento com a República, longe de ser inclusiva, é por sua natureza profundamente assimétrica, chega mesmo a ser iníqua, mas também, reconhecidamente eficiente para o seu desígnio, pois domina a partir de um "consenso", ao invés da imposição cruel com mecanismos de força física (usada apenas em ocasiões especiais).

Mesmo sabendo que essa modalidade de dominação invisível ou não visível, também carrega seu grau de crueldade por seus efeitos perversos e que não deixa de exercer violência psicológica, ela parece e aparece nas suas formas possíveis de percepção e apreensão, como sendo menos maléfica do que a violência visível ou até mesmo a disfarça quando, por exemplo, a polícia comandada pelo Estado executa uma ação de despejo ou reintegração de posse de uma área ou propriedade privada em nome do direito e, principalmente, da manutenção da ordem. Ordem que foi constituída "teoricamente" por todos e para todos, portanto, legítima e legal.

Essa fascinante representação da estrutura do dispositivo legal também opera no nível das relações Estados - União. Porém, nesse campo os contendores são mais sofisticados e o mero discurso raramente convence ou emociona os interlocutores, então surge à necessidade de remontar as bases de apoio para lhes dar substância. Nesse caso a recorrência, o apelo a um passado heroico, o orgulho de ser isto ou aquilo, ou a convocação de um passado históri- 
co de lutas, unidade, diferenças com relação aos outros, etc., torna-se necessário para fortalecer as reivindicações locais e renovar a convicção de todos, seja na comemoração de uma vitória, seja na resignação de uma demanda não atendida.

Nessa movimentação de mentes, corações e, principalmente, de braços produtivos revitalizam-se as arquiteturas sociais projetadas e executadas pelo cume da pirâmide social, mas sempre articulando sua ressonância na base, como meio de manutenção de um projeto que é perenizado, renovado e sem sombra de dúvidas, bem cimentado pela ideologia de que o interesse social comanda todos os processos. Os vencedores convidam os vencidos para participar da festa da vitória, ainda que seja no final para limpar o salão.

O Acre e o Rio Grande do Sul, portanto, tão distantes geograficamente, se aproximaram ao longo do tempo pela articulação de um discurso que desde sua invenção nos processos de suas formações como unidades federativas, vêm conduzindo sua linha de relacionamento com a União. A condição de filho optante ou enjeitado, além de forte coesão interna, permite olhar e ser olhado de forma diferenciada nas suas relações, tanto de dentro para fora quanto de fora para dentro no contexto republicano.

Por fim, faz-se mister apontar que outras unidades federativas e até mesmo regiões, também se valem ou tentam se valer de elementos valorativos, de condicionamentos que os fazem diferentes, tais como o "orgulho de ser nordestino”, ou a exaltação da economia paulistana, o caráter revolucionário do pernambucano, etc., peculiaridades que são também potencializadas para regular relacionamentos políticos-institucionais no âmbito interno e da União, mas que nunca atingiram o nível das feições e coesão que marcam gaúchos e acreanos.

\title{
BRAZILIAN BY OPTION: SOME PECULIARITIES IN THE PROCESS OF POLITICAL EMANCIPATION BETWEEN ACRE AND RIO GRANDE DO SUL
}

\begin{abstract}
Presents theoretical reflections on elements identitary used per Acre and gauchos, retracing the historicals scrapbooks and historiographys, in two states,
\end{abstract}


are looking to build distinctive peculiarities of its national character. The statements of Brazilianness optative that characterize them, are part of a discourse appropriate for sectors leaders and other social segments that, not infrequently, projecting ambiguous feelings, ranging from the distinction of positive acreanidade/gauches, from the point of the connotation of "children risk" of the nation, which is expressed in a more acute in letters of his hymns, especially when highlighting the mighty acts of bravery in their struggles "independence" against foreigners.

KEY WORDS: Identity. Acreano. Gaucho. Symbol. Representation.

\section{Referências}

ANDERSON, P. As antinomias de Gramsci. Crítica Marxista (São Paulo: Joruês):7-74, 1986.

COUTINHO, C. N. \& NOGUEIRA, M. A. (org.) Gramsci e a América Latina. Rio de Janeiro: Paz e Terra, 1985.

MACIEL. M. E. Os Tipos Característicos. Região e estereótipos regionais. In. Humanas, Porto Alegre, 1995. v. 18, n.1/2.

OLIVEN, R. G. A parte e o todo: a diversidade cultural no Brasil-nação. Petrópolis: Vozes, 1992.

PESAVENTO, S. J. Região e Nação: as releituras do Brasil em tempo de Democracia. In. Humanas, Porto Alegre, 1995. v. 18, n.1/2.

REVISTA GALVEZ. Publicada pela Sec. de Cultura do Governo do Estado do Acre. n. 1 a 12,2002 a 2004.

SANTOS, R. A. O. História Econômica da Amazônia: 1800-1920. São Paulo, T.A. Queiroz, 1980.

SOUZA, S. B. Identidade e Nacionalismo no Processo de Integração da Fronteira Uruguaia no Final do Século XIX. . In. Humanas, Porto Alegre, 1995. v. 18, n.1/2.

TOCANTINS, L. Formação Histórica do Acre. Rio de Janeiro: Civilização Brasileira; Brasília: INL/Conselho Federal de Cultura; Rio Branco: Governo do Estado do Acre, 1979. vol. I e II.

Data de recebimento: 20/08/2014

Data de aceite: 29/09/2014 